\title{
PENERAPAN METODE EXTREME PROGRAMMING DALAM MENGEMBANGKAN APLIKASI PEMASUKAN DAN PENGELUARAN KAS BERBASIS WEB
}

\author{
Ardiyansyah, Deni Risdiansyah, Rizki Faturahman \\ Program Studi Sistem Informasi Akuntansi Kampus Kota Pontianak, Universitas Bina Sarana Informatika \\ Jl. Abdurrahman Saleh No.18A, Pontianak \\ ardiyansyah@bsi.ac.id, deni.drx@bsi.ac.id, rizkifaturiz03@gmail.com
}

\begin{abstract}
CV. Derwati is a private company engaged in trading, namely as a supplier of bookstores and props. Financial processing system on CV. Derwati Pontianak currently still uses books as a record of cash income and expenditure, Microsoft excel is used to recap data as financial reports. Problems that occur include frequent loss of income and expenditure data, difficulty in searching for data and financial reports which often occur out of sync. In this research, the researcher designs and builds cash income and disbursement applications using the extreme programming method. The purpose of this research is to be able to record cash income and expenditure transactions properly, data is stored safely, easy to search data, helps and makes it easier for users to process finances. Based on this description, the conclusion that can be drawn is to use the income and expenditure method which was developed with extreme programming, which can make it easier for users to manage finances and provide financial reports.
\end{abstract}

Keywords - extreme programming, cash inflow, cash out, software development.

\begin{abstract}
Abstrak - CV. Derwati merupakan perusahaan swasta yang bergerak dibidang dagang yaitu sebagai supplier toko buku dan alat peraga. Sistem pengolahan keuangan pada CV. Derwati Pontianak saat ini masih menggunakan buku sebagai pencatatan pemasukan dan pengeluaran kas, Microsoft excel digunakan untuk merekap data sebagai laporan keuangan. Masalah yang terjadi diantaranya sering terjadi kehilangan data pencatatan pemasukan dan pengeluaran, sulit melakukan pencarian data dan laporan keuangan yang dibuat sering mengalami tidak singkron. Pada penelitian ini, peneliti merancang dan membangun aplikasi pemasukan dan pngeluaran kas dengan menggunakan metode extreme programming. Tujuan dari penelitian ini adalah dapat mencatat transaksi pemasukan dan pengeluaran kas dengan baik, data tersimpan dengn aman, mudah melakukan pencarian data, membantu dan mempermudah pengguna dalam mengolah keuangan. Berdasarkan uraian tersebut, kesimpulan yang dapat diambil yaitu dengan adanya aplikasi pemasukan dan pengeluaran kas yang dikembangkan dengan menggunakan metode extreme programming dapat mempermudah pengguna dalam pengelolaan keuangan serta menyediakan laporan keuangan.
\end{abstract}

Kata Kunci - extreme programming, pemasukan kas, pengeluaran kas, software development.

\section{PENDAHULUAN}

Penggunaan sebuah teknologi dalam pengolahan data menjadi hal yang penting dalam memberikan sebuah informasi kepada pengguna. Selain memberikan sebuah informasi, teknologi juga membantu pengguna dalam mengatasi masalah yang terjadi. Pada era modern saat ini banyak manfaat yang dirasakan oleh masyarakat dari penggunaan teknologi tersebut.

CV. DERWATI sendiri merupakan perusahaan milik swasta yang bernaung dalam usaha sebagai supplier toko buku dan alat peraga ke berbagai tempat. Tentu saja sebagai supplier buku dan alat peraga, CV. DERWATI memiliki cukup banyak data yang belum terorganisir dengan baik, terutama dalam bidang pencatatan penerimaan dan pengeluaran dana keuangan. Aliran kas (cash flow) adalah sejumlah kas yang masuk dan keluar dari aktivitas transaksi perusahaan. Pemasukan kas merupakan kas yang diterima sebagai keuntungan perusahaan dari kegiatan transaksi, sedangkan pengeluaran kas merupakan kas yang harus dikeluarkan sebagai biaya dari kegiatan transaksi perusahaan [1]. Sistem pengolahan keuangan pada CV. Derwati Pontianak saat ini masih menggunakan buku sebagai pencatatan pemasukan dan pengeluaran kas, dan MS.Excel digunakan untuk merekap data pemasukan dan pengeluara kas. Sehingga masalah yang sering terjadi adalah data pemasukan dan pengeluaran sering terlewat untuk dicatat, data yang tercatat dibuku juga sering mengalami kerusakan bahkan kehilangan, data yang direkap juga sering terjadi kesalahan seperti tidak singkron antara pencatatan dengan keuangan yang ada.

Melihat dari permasalahan yang terjadi maka perlu dibuatkan aplikasi yang dapat mencatat pemasukan dan pengeluaran kas, menyimpan data, dapat mempermudah dalam pencarian data dan dapat menghasilkan laporan keuangan pemasukan, pengeluaran dan laba rugi yang sesuai dengan pencatatan pemasukan dan pengeluaran yang di input. Sehingga peneliti tertarik melakukan penelitian dengan merancang dan membangun aplikasi pemasukan dan pengeluaran kas sebagai pemecahan masalah tersebut. 
Penelitian tentang aplikasi pemasukan dan pengeluaran kas sudah banyak dilakukan oleh peneliti lain seperti, System Informasi Pencatatan Arus Kas (SIPAS) Pada PKBM Negari 23 Kebon Melati Jakarta Menggunakan Model Waterfall [3]. Sistem Informasi Akuntasi Arus Kas Pada Kantor Desa Bobaneigo Kec.Kao Teluk Kabupaten Halmahera Utara [4]. Pengembangan Sistem Informasi Arus Kas Dengan Metode SDLC (System Development Life Cycle) pada Madin Al-Junnah [5]. Sistem Informasi Akuntansi Penerimaan Dan Pengeluaran Kas Dalam Meningkatkan Pengendalian Internal Atas Pendapatan Pada Rsup Dr. Kariadi Semarang [6].

Dalam penelitian ini, peneliti menggunakan metode extreme programming yang merupakan turunan dari metode agile. Metode extreme programming digunakan sebagai pengembangan perangkat lunak. Pemilihan metode extreme programming dalam peneitian ini disebabkan metode extreme programming memiliki nilai fleksibel yang tinggi dalam proses perubahan maupun dalam proses pengembangan perangkat lunak [2].

Tujuan dari penelitian ini adalah dengan adanya aplikasi pemasukan dan pengeluaran kas ini diharapkan dapat mencatat transaksi pemasukan dan pengeluaran kas dengan baik, data dapat tersimpan dengn aman, mudah untuk melakukan pencarian data, dapat membantu dan mempermudah pengguna dalam mengolah keuangan terutama pada pemasukan dan pengeluaran kas perusahaan, memberikan laporan keuangan yang dapat mengetahui laba atau rugi dan dapat mengatasi masalah-masalah yang sering terjadi.

\section{METODE PENELITIAN}

Metode yang di pilih untuk merancang dan mengembangkan aplikasi pemasukan dan pengeluaran berbasis web ini menggunakan pendekatan agile software development yaitu metode extreme programming [7]. Metode extreme programming dipilih sebagai metode yang lebih fleksibel dan cepat dalam merancang dan mengembangkan sebuah aplikasi [7].

Metode XP meliputi beberapa tahapan, mulai dari tahap awal yaitu perencanaan (planning), perancangan (design), pengkodean (coding), pengujian (testing), peningkatan perangkat lunak (software increament) [7].

Pada tahap perencanaan dilakukan dengan mengidentifikasi masalah yang terjadi pada perusahaan atau instansi, menganalisa kebutuhan yang sesuai dengan kebutuhan perusahaan. Dalam tahapan ini, peneliti mengumpulkan data-data yang dibutuhkan untuk merancang aplikasi dengan berbagai metode seperti melakukan observasi ke lokasi penelitian untuk mendapatkan informasi dan peneliti dapat menganalisa kebutuhan yang dibutuhkan oleh objek penelitian. Selain melakukan observasi, peneliti juga melakukan wawancara kepada objek penelitian untuk mengetahui masalah yang sering terjadi dalam mengolah pemasukan dan pengeluaran kas.

Setelah data yang dikumpulkan pada tahap perencanaan sudah cukup, selanjutnya adalah melakukan perancangan aplikasi. Dalam aplikasi yang akan dibangun terdapat tiga hak akses yaitu admin dan bendahara dapat mengolah data user, data pegawai, metode pembayaran, kategori pembayaran, produk, customer, data kas masuk dan data kas keluar. Sedangkan pimpinan dapat mengolah data laporan pemasukan, laporan pengeluaran dan laporan laba rugi. Peneliti juga menggunakan pemodelan UML (unified modeling language) sebagai metode perancangan system berbasis objek. Sedangkan ERD (Entity relationship diagram) dan LRS (logical record structure) digunakan sebagai pemodelan basisdata yang didasari antara objek yang saling berhubungan.

Tahap selanjutnya coding yaitu implementasi dari tahap design menjadi sebuah aplikasi dengan memanfaatkan Hypertext Markup Language (HTML), Hypertext Preprocessor (PHP), Cascading Style Sheets (CSS), Java script dan jQuery sebagai bahasa pemrograman di tahap coding tersebt. Sedangkan web server local, peneliti menggunakan aplikasi XAMPP dan visual studio code sebagai aplikasi editor dan menggunakan framework codeigniter versi 3.

Tahap terkahir adalah pengujian dan peningkatan perangkat lunak. Tahap pengujian ini dilakukan untuk menentukan kelayakan sebuah perangkat lunak yang dibangun apakah sudah sesuai dengan kebutuhan pengguna atau tidak dan untuk meminimalisir kesalahan aplikasi sehingga aplikasi yang dibangun benar-benar membantu pengguna. Untuk melakukan pengujian dalam pembuatan aplikasi, peneliti melakukan pengujian ini menggunakan blackbox testing. Pada tahap peningkatan perangkat lunak, tahap ini melakukan pemantauan secara berkala pada perangkat lunak yang sudah di implementasikan dan akan melakukan perkembangan perangkat lunak sesuai kebutuhan pengguna.

\section{HASIL DAN PEMBAHASAN}

Berdasarkan uraian yang dijelaskan pada metode penelitian, pada bagian ini akan dijelaskan hasil atas penelitian yang dilakukan sebagai pokok pembahasan di penelitian ini.

A. Analisa Kebutuhan Fungsional

Berdasarkan hasil dari analisa kebutuhan, terdapat tiga hak akses dalam aplikasi pemasukan dan pengeluaran kas berbasis web. Setiap level akses memiliki kebutuhan system yang berbeda dan cara interaksi tersendiri. Berikut analisa kebutuhan fungsional berdasarkan setiap level akses: 
1. Admin
a. Admin Login
b. Admin Mengelola Data User
c. Admin Mengelola Data Master
d. Admin Mengelola Data Transaksi
e. Admin Mengelola Data Laporan

2. Bendahara
a. Bendahara Login
b. Bendahara Mengelola Data Master
c. Bendahara Mengelola Data Transaksi
d. Bendahara Mengelola Data Laporan

3. Direktur
a. Direktur Login
b. Direktur Melihat Data Master
c. Direktur Melihat Data Laporan

B. Use Case Diagram

Use case diagram digunakan untuk menggambarkan peran pengguna terhadap aplikasi [8]. Selain itu, use case diagram digunakan untuk mengetahui fungsi apa saja yang terdapat dalam aplikasi dan siapa saja yang memiliki hak untuk mengakses sebuah aplikasi [9]. Berikut adalah salah satu gambaran use case diagram sesuai kebutuhan hak akses pengguna.

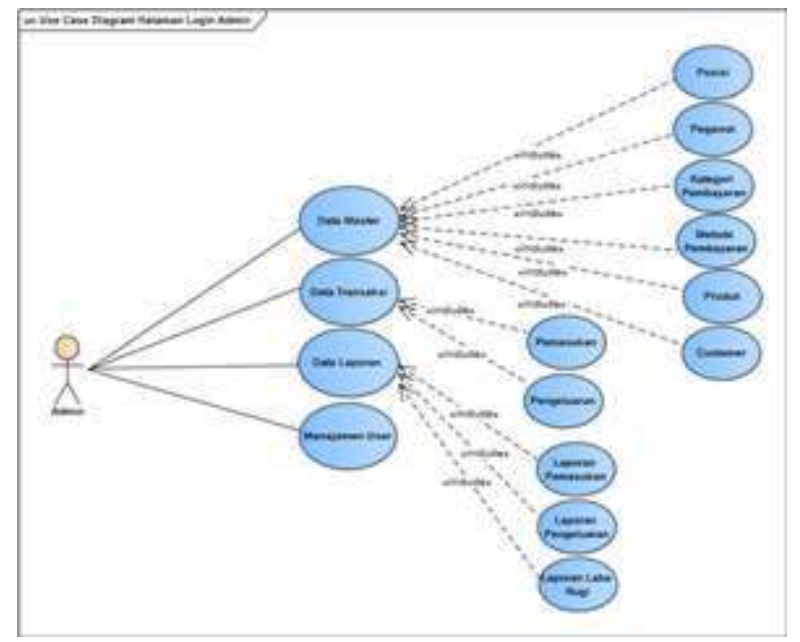

Gambar 1. Use Case Diagram Admin

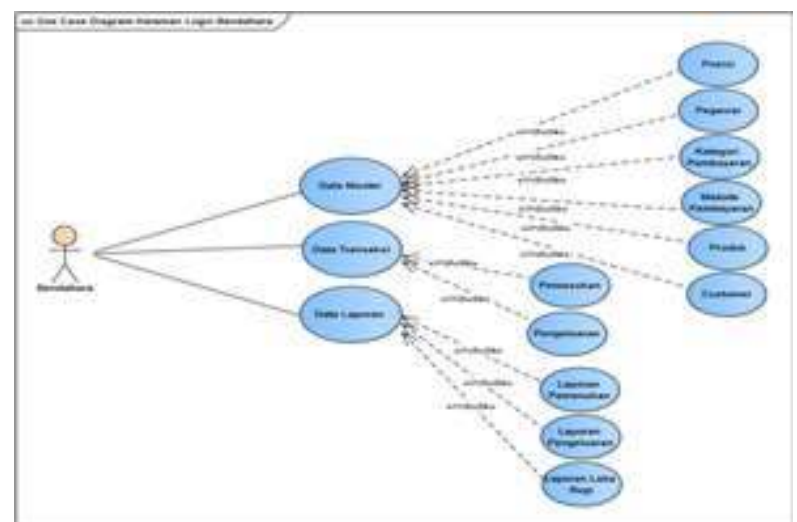

Gambar 2. Use Case Diagram Bendahara

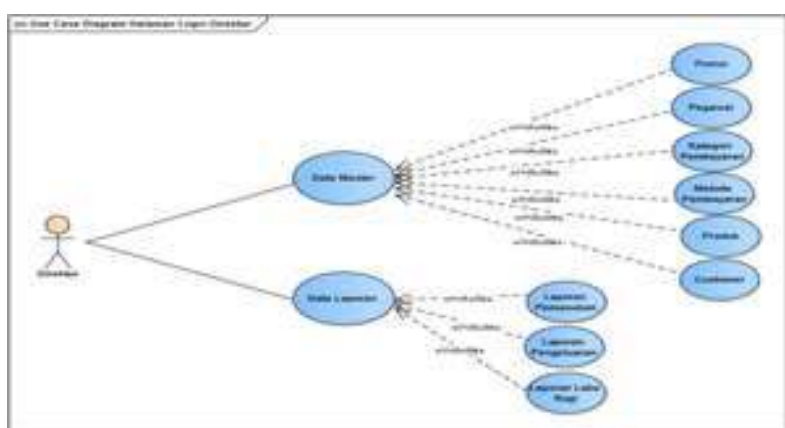

Gambar 3. Use Case Diagram Direktur

\section{Activity Diagram}

Activity diagram digambarkan dengan tujuan memberikan gambaran workflow dari sebuah aplikasi yang berhubungan dengan aplikasi [10]. Berikut adalah activity diagram pada sistem pemasukan kas dan pengeluaran kas:

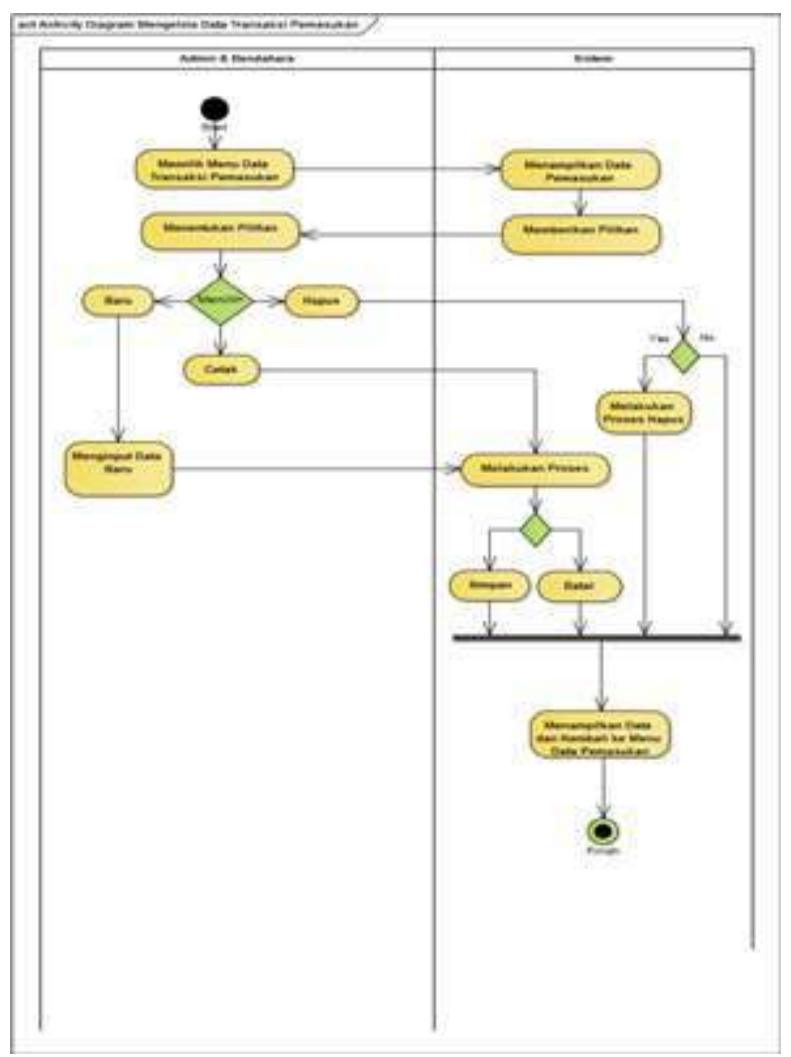

Gambar 4. Activity Diagram Pemasukan 


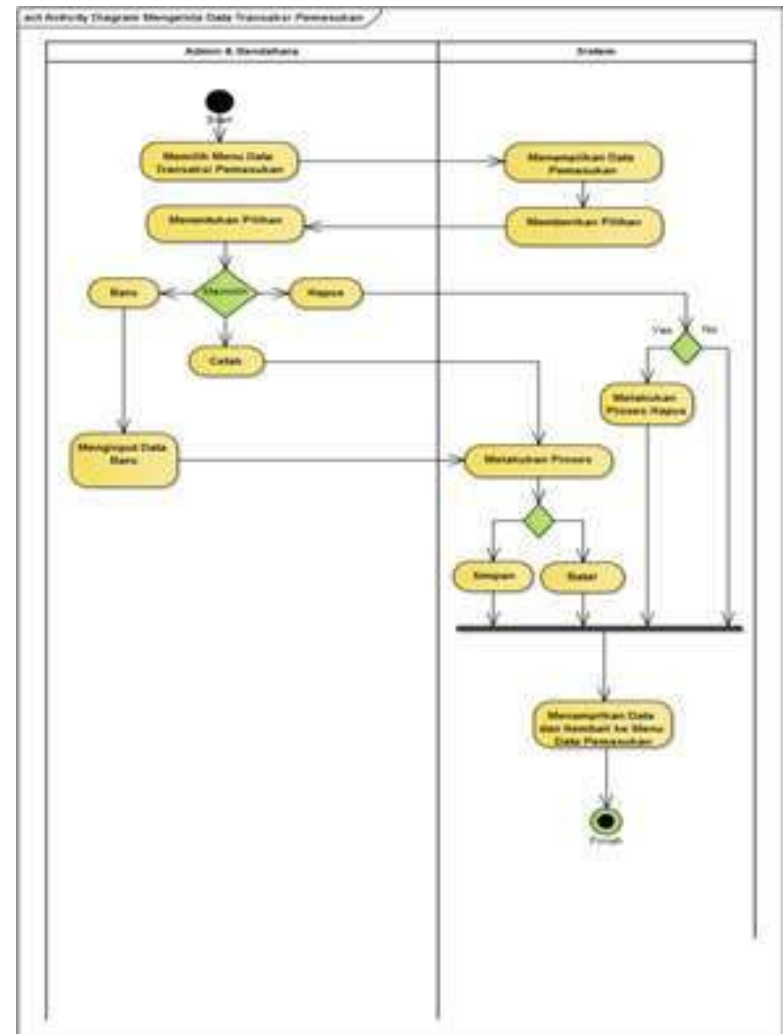

Gambar 5. Activity Diagram Pengeluaran

\section{Class Diagram}

Class Diagram membantu dalam visualisasi kelas dari sebuah sistem, hal ini disebabkan class diagram mendeskripsikan kelompok objek-objek dengan atribut (property), perilaku (operation), dan relasi yang sama. Berikut ini gambaran mengenai sistem dan relasi-relasi didalamnya dalam bentuk class diagram yang dirancang:

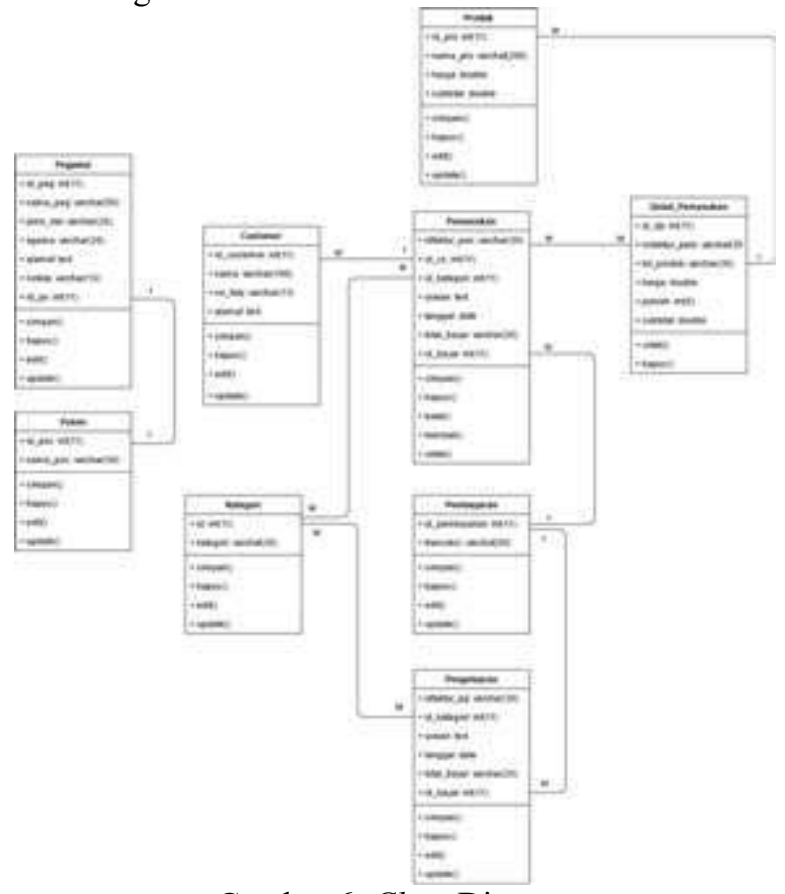

Gambar 6. Class Diagram
E. Logical Record Structure (LRS)

Logical Record Structure (LRS) adalah representasi dari struktur record-record pada tabel-tabel yang terbentuk dari hasil antar himpunan entitas. menentukan kardinalitas, jumlah tabel dan Foreign Key (FK). Berikut LRS pada aplikasi pemasukan dan pengeluaran kas berbasis web:

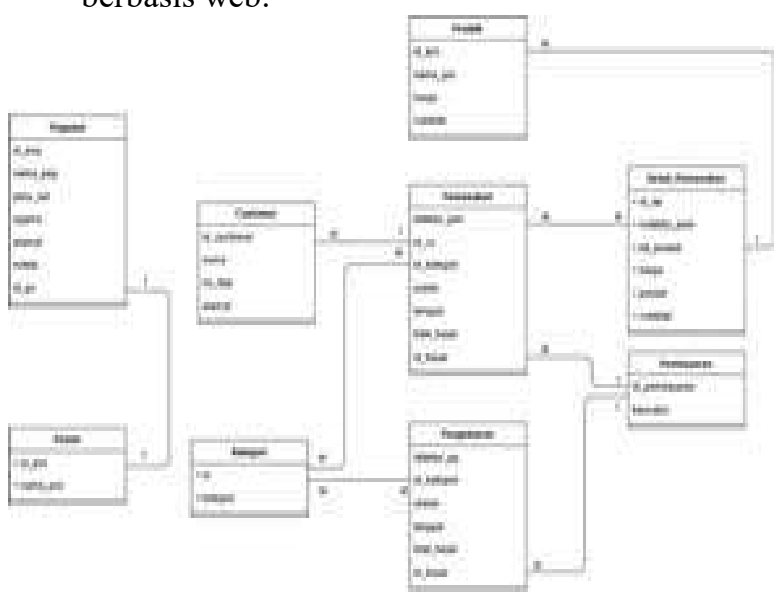

Gambar 7. Logical Record Structure (LRS)

F. Implementasi Aplikasi

Pada bagian ini, peneliti akan menampilkan hasil dari aplikasi yang sudah dibangun. Berikut adalah interface aplikasi pemasukan dan pengeluaran kas berbasis web:

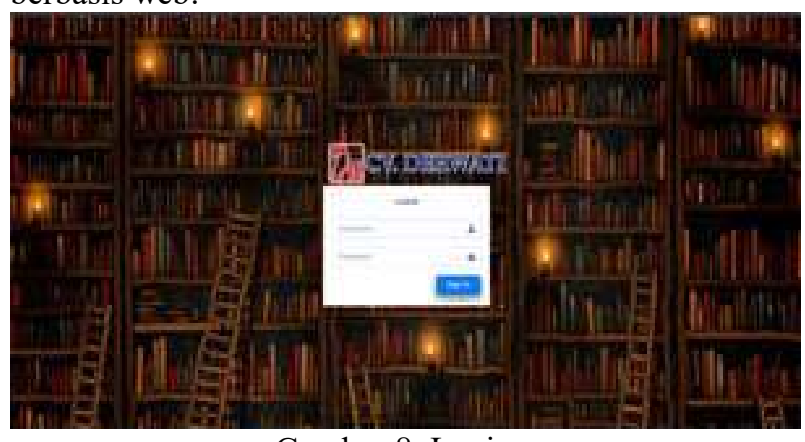

Gambar 8. Login

Pada gambar 8, pengguna dapat masuk ke system dengan melakukan login terlebih dahulu yaitu dengan menggunakan username dan password yang sudah di tentukan.

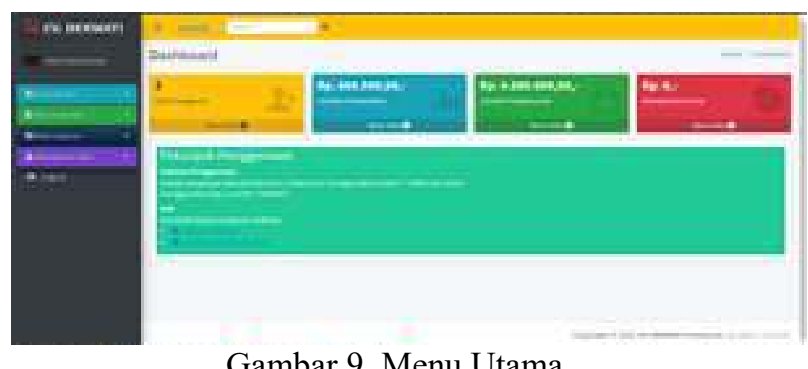

Setelah login, pengguna akan masuk ke halaman menu utama. Pada menu utama ini akan tersedia 
beberapa fitur seperti petunjuk dalam penggunaan aplikasi, jumlah dana pemasukan, jumlah dana pengeluaran, laba rugi dan jumlah pengguna.

Pada gambar 10 dan 11 merupakan salah satu data master yang digunakan untuk menyimpan data produk dan customer. Pada data master terdapat tampil data, tambah, hapus dan edit data.

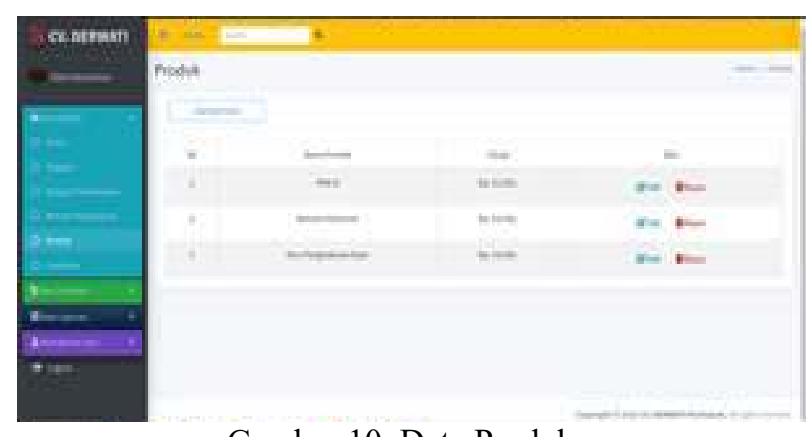

Gambar 10. Data Produk

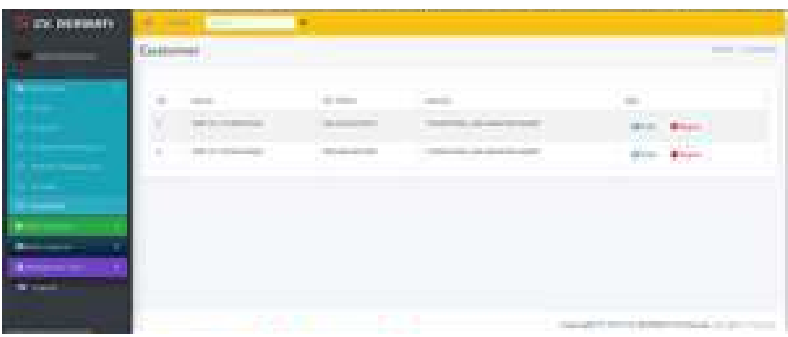

Gambar 11. Data Customer

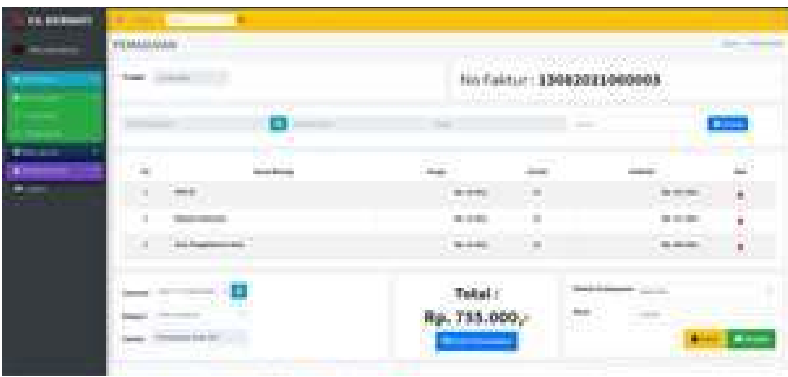

Gambar 12. Transaksi Pemasukan

Pada transaksi pemasukan berisi no faktur, produk-produk yang di jual sebagai pemasukan, data customer, data kategori serta metode pembayaran.

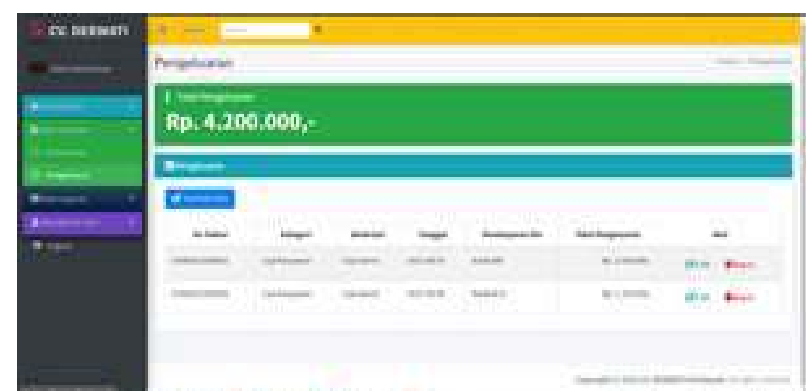

Gambar 13. Transaksi Pemasukan
Pada transaksi pengeluaran berisi no faktur, kategori, deskripsi, tanggal serta metode pembayaran. Selain itu terdapat tombol tambah, edit dan hapus data.

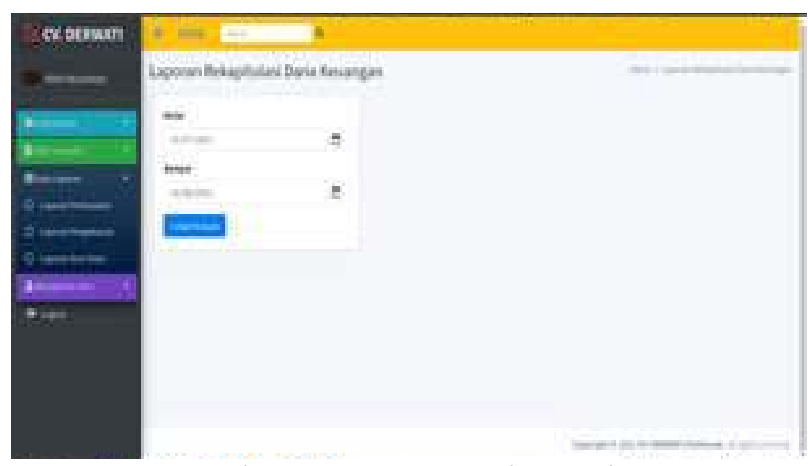

Gambar 14. Laporan Laba Rugi

Pada laporan keuangan, pengguna dapat memfilter berdasarkan tanggal yang di pilih, dapat memfilter berdasarkan hari, minggu dan bulan.

\section{G. Pengujian Aplikasi}

Pengujian aplikasi dilakukan untuk mengetahui apakah aplikasi berjalan sesuai kebutuhan atau tidak dan dijadikan sebagai bahan evaluasi [11]. Metode yang digunakan dalam pengujian aplikasi ini adalah black box testing. Metode Black Box Testing adalah metode pengujian yang digunakan untuk mengetahui apakah semua fungsi software berjalan sesuai kebutuhan fungsional yang telah ditentukan [12].

Kesimpulan dari pengujian yang dilakukan terhadap aplikasi pemasukan dan pengeluaran kas berbasis web, semua fungsi serta komponenkomponen yang ada pada aplikasi mulai dari form login, data-data master, data transaksi pemasukan dan pengeluaran serta laporan memberikan hasil pengujian yang valid atau sesuai kebutuhan pengguna.

\section{KESIMPULAN}

Berdasarkan uraian pada metode penelitian, implementasi dan pengujian yang dilakukan pada penelitian ini, maka dapat diambil kesimpulan sebagai berikut :

1. Aplikasi pemasukan dan pengeluaran kas yang dibangun menggunakan metode extreme programming dapat digunakan sebagai aplikasi yang mempermudah dan membantu pengguna untuk mengolah dana keuangan baik sebagai pemasukan maupun pengeluaran.

2. Aplikasi pemasukan dan pengeluaran kas yang dibangun dapat memberikan informasi mengenai keuntungan atau kerugiaan perusahaan berdasarkan laporan keuangan laba rugi yang disajikan pada aplikasi tersebut.

3. Sebagai pengembangan selanjutnya, aplikasi pemasukan dan pengeluaran kas berbasis web ini dapat di kembangkan dengan menambahkan beberapa fitur laporan keuangan seperti laporan 
jurnal umum, buku besar dan lain-lain. Selain itu, aplikasi ini tidak hanya berbasis web tetapi akan di bangun lagi menjadi aplikasi pemasukan dan pengeluaran kas versi mobile.

\section{DAFTAR PUSTAKA}

[1] K. Purwantini, Elisa Satyaningrum, and Arsito Ari Kuncoro, "Sistem Informasi Arus Kas Berbasis Multi User Pada Sekolah Kb-Tk Kristen Dian Wacana Demak," Kompak J. Ilm. Komputerisasi Akunt., vol. 13, no. 2, pp. 1-10, 2020, doi: 10.51903/kompak.v13i2.275.

[2] F. Fatoni and D. Irawan, "Implementasi Metode Extreme Programming dalam Pengembangan Sistem Informasi Izin Produk Makanan," J. Sisfokom (Sistem Inf. dan Komputer), vol. 8, no. 2, pp. 159-164, 2019, doi: 10.32736/sisfokom.v8i2.679.

[3] I. Rusdi and F. Andriani, "Sistem Informasi Pencatatan Arus Kas ( SIPAS ) Pada PKBM Negari 23 Kebon Melati Jakarta Menggunakan Model Waterfall," Smart Comp, vol. 10, no. 2, 2021.

[4] M. Abdurahman, A. Thalib, and A. Ambarita, "Sistem Informasi Akuntasi Arus Kas Pada Kantor Desa Bobaneigo Kec.Kao Teluk Kabupaten Halmahera Utara," IJIS - Indones. J. Inf. Syst., vol. 4, no. 2, pp. 78-86, 2019, doi: 10.36549/ijis.v4i2.56.

[5] S. B. Hartono, "Pengembangan Sistem Informasi Arus Kas Dengan Metode Sdlc (System Development Life Cycle) Pada Madin Al-Junnah," ISOQUANT J. Ekon. Manaj. dan Akunt., vol. 4, no. 1, p. 1, 2020, doi: 10.24269/iso.v4i1.337.

[6] F. P. Ardani, "PENGENDALIAN INTERNAL ATAS PENDAPATAN PADA RSUP Dr . KARIADI SEMARANG PENGENDALIAN INTERNAL ATAS PENDAPATAN."

[7] Ardiyansyah and R. Pratama, "Rancang Bangun Sistem Informasi Penjualan Kredit (Sijudit) Berbasis Web Dengan Metode Extreme Programming Pada Pt. Heroes Adhimulia Pontianak," J. Inform. Kaputama, vol. 5, no. 2, pp. 301-308, 2021.

[8] E. Meilinda, "Perancangan Aplikasi Kearsipan Surat Menyurat Pada Badan Pemerintahan (Studi Kasus : Badan Pemberdayaan Perempuan Perlindungan Anak Dan Keluarga Berencana Pontianak)," J. Khatulistiwa Inform., vol. IV, no. 2, pp. 144-152, 2016.

[9] A. Hendini, "Pemodelan UML Sistem Informasi Monitoring Penjualan Dan Stok Barang (Studi KASUS: Distro Zhezha Pontianak)," J. KHATULISTIWA Inform., vol. IV, no. 2, pp. 107-116, 2016.
[10] H. Setiawan and K. M.Qadafi, "Perancangan Sistem Informasi Manajemen Proyek : Sistem Informasi Kontraktor," J. KHATULISTIWA Inform., vol. V, no. 2, pp. 28-39, 2017.

[11] N. P. Dewi and R. A. Fadlillah, "INVENTORI BERBASIS WEB DAN ANDROID," vol. 5, no. $1,2021$.

[12] U. Ependi, P. S. Informatika, I. Komputer, and U. B. Darma, "ISSNOnline : 2355-4614 Uji Coba Dan Implementasi Test Engine System Bina Darma Career And Training ISSNOnline : 2355-4614," vol. 9, no. 1, pp. 1222-1232, 2017. 